\title{
Analysis on the Standards of Indirect Expropriation in International Investment
}

\author{
Li Ying ${ }^{1} \mathrm{Yu} \mathrm{Di}^{2}$ \\ ${ }^{1}$ School of Humanities and Social Sciences, North China Electric Power University, Beijing, China \\ ${ }^{2}$ School of Humanities and Social Sciences, North China Electric Power University, Beijing, China
}

\begin{abstract}
Being the core issue of international investment, the standards are confirmed to distinguish indirect expropriation from general regulatory measures implemented by the host country. However, the standards have not been regulated definitely by International Investment Treaties. In the name of general regulatory measures, some of the host countries refuse to compensate for foreign investors by indirect expropriation. This paper first summarizes the standards of indirect expropriation, and then makes a deeply analysis on them, after which comes up with the assumption that the standards of indirect expropriation should take the standard of Effect and Purpose Test into account.
\end{abstract}

Keywords: International Investment, Indirect Expropriation, Standards, General Regulatory Measures.

\section{The Standards of Indirect Expropriation}

Clarifying the standards of indirect expropriation is significant for the division of indirect expropriation from the general regulatory measures imposed by the host country. According to relevant international conventions, if the action of the host country is identified as indirect expropriation, the host country must undertake obligation of compensating for the loss of foreign investors; however, if it is identified as general regulatory measure, no compensation is needed. So identifying the standards of indirect expropriation helps define the rights and obligations of the host country and its protection level to the property rights of foreign investors, as well as balance the interests between host countries and foreign investors.

From the Bilateral Investment Treaties, regional multilateral investment treaties and universal international conventions signed by countries, the standards of indirect expropriation can be summarized as the following three categories: (1) the standard of Sole Effect Test; (2) the standard of Purpose Test; (3) the standard of Effect and Purpose Test.

\subsection{The Standard of Sole Effect Test}

The standard of Sole Effect Test refers that the identification of indirect expropriation is solely determined by the influence of the host government's measure on the properties of foreign investors. Andrew
Newcombe, an arbitrator in International Court of Arbitration, cited the case of Starrett Housing Corporation v. Islamic Republic of Iran to explain this standard, namely, because of the intervention of the host country, foreign investors' property rights are considered worthless; then even if the host country does not claim expropriation and private property rights are still controlled by foreign investors themselves, it must be identified as indirect expropriation due to the extent of effect.[1]

The standard of Sole Effect Test is harmful to the public interests of sovereign states, so it could be hardly found in domestic law or Bilateral Investment Treaties; however, it is adopted by several arbitral tribunals. For example, Iran - U.S. arbitral tribunal applies the standard of Sole Effect Test in identifying indirect expropriation: as long as the action of Iranian government adversely influences the property rights and benefits American investors to some degree, the arbitral tribunal would identify the action as indirect expropriation. In the case of Tippetts v. Iran[2], the arbitral tribunal found that the host country deprived foreign investors of their property rights and benefits, and this deprivation was not temporary, so the arbitral tribunal decided that expropriation had occurred and supported Tippetts' claim of indirect expropriation.

\subsection{The Standard of Purpose Test}

The standard of Purpose Test refers that the identification of indirect expropriation is determined by the purpose of the host country: if the action of the host country is consistent with the following conditions, it can't be identified as indirect expropriation, and the host government needn't compensate foreign investors for their losses. The following conditions are: (i) the indirect expropriation shall be done for public interest; (ii) shall under domestic legal procedures; (iii) shall not be discriminatory.

The standard of Purpose Test emphasizes the maintenance of public interests of the host country. Once clearly reflected in the law, it would seriously attack foreign investment into the host country. So, few host countries bring this standard into laws, but apply it into practice. For example, Argentine Foreign Investment Law implemented in 1973 does not contain special clauses for expropriation, but after the economic crisis broke out in Argentina during 2001 and 2002, the government implemented a large scale of regulatory 
actions to foreign investment, including indirect expropriation. Subsequently, in a number of ICSID arbitration cases, Argentine government, as the defendant, advocated that its action aimed to safeguard public interests and abided by police power, so it was general regulatory measure. This view gained support from the arbitral tribunal.

\subsection{The Standard of Effect and Purpose Test}

The standard of Effect and Purpose Test refers that both the effect and purpose of the host country' action should be taken into consideration when identifying indirect expropriation. Namely, whether the action of the host country causes some adverse influence to the rights and interests of foreign investment, and whether the action itself is in compliance to the prerequisite of public interests determine whether the action can be identified as indirect expropriation. If the action of the host country adversely influences the rights and interests of foreign investors to some degree, even under the prerequisite of public interests, it is also identified as indirect expropriation.

Some domestic laws and Bilateral Investment Treaties adopt the standard of Effect and Purpose Test to identify indirect expropriation. For example, Article 61 of the Lao People's Democratic Republic Investment Law implemented in 2009 amplifies that a prerequisite for Lao government to compensate foreign investors is that foreign investors has been expropriated and at the same time the expropriation is for domestic public interests. The former applies the standard of Sole Effect Test and the latter takes the standard of Purpose Test into consideration. In practice, because modern International Law emphasizes the balance of interests, International Arbitration Tribunal prefers to apply the standard of Effect and Purpose Test, with which the host country and foreign investors have less disagreement. The standard of Effect and Purpose Test is conducive to the allocation of rights and obligations between the host country and foreign investors. Therefore, the verdicts of International Arbitration Tribunal in accordance to it have a higher degree of recognition and enforcement. In Lauder $\mathrm{v}$ Czech Republic case[3] under United Nations Commission on International Trade Law Arbitration Rules (UNCITRAL Arbitration Rules), the Dutch subsidiary of American investor Lauder, CME, held the equity of company Czech. The arbitral tribunal identified the action of Czech government as indirect expropriation when the property rights of foreign investors had been adversely influenced.

\section{Analysis on the Standards of Indirect Expropriation}

\subsection{Analysis on the Standard of Sole Effect Test}

To the maximum extent, the standard of Sole Effect Test limits the management right of the host country and protects the rights and interests of foreign investors. In the international investment process, as long as the host country's action makes adverse influence on foreign investment, it tends to be identified as indirect expropriation, and whereby foreign investors can claim corresponding compensation. In the 1980s and 1990s, a wide range of developed countries played the role of investing countries in international investment process. Because the standard of Sole Effect Test can provide sufficient protection for domestic investors to invest abroad, so they preferred to apply it in a large degree. In today's international community, more attention has been paid to the issues like human rights and environmental protection. If foreign investors are allowed to invest in the host country freely regardless of those issues in the host country, the development course of international investment must be violated, which is harmful to the development balance of global economy and society.

\subsection{Analysis on the Standard of Purpose Test}

The standard of Purpose Test is beneficial for the host country's practice of management rights under specific domestic circumstances, and thus it better protects the public interests of the host country. However, according to this test, if the action of the host country is consistent with the public interests, non-discriminatory, and follows the provisions of relevant laws, the host country will not provide compensation for foreign investors, which is not conducive for the host country to attract foreign investment. Compared with the standard of Sole Effect Test, the standard of Purpose Test maintains more subjectivity, so the host country is likely to implement destructive interference on the justification of public interests, which will undoubtedly increase uncertainty of foreign investors' prospect in the host country.

The biggest problem occurred in the standard of Purpose Test is how to define public interests. Till now, the concept of public interests has no clear definition: some scholars hold that it refers to the interests of the community as a whole, including health, safety, morality, security, revenue and police rules and so on, whose purpose is the convenience, security and interests of the whole society rather than specific individual or individuals. [5]Besides, there are no clear standards and judgment methods of public interests for their connotation and extension changes with economic and social development as well as the changes of people's values. The public interests in most countries generally include public facilities, public utilities, social welfare, transportation construction, urban planning and so on. In recent years the environmental protection, public health and human rights protection are also included.

\subsection{Analysis on the Standard of Effect and Purpose Test}

The standard of Effect and Purpose Test not only takes into account the foreign capital management right of the host country, but also limits the host country to exercise this right to some extent and thus the property rights of foreign investors can be protected. With integrated consideration of subjective and objective factors, the standard of Effect and Purpose Test has relatively strong operability, effectively balancing the interests of the host 
country and foreign investors, thereby gaining more support both theoretically and practically.

Introducing the principle of proportionality into the standard of Effect and Purpose Test breaks the traditional standard of Sole Effect Test and standard of Purpose Test. It takes both the effect and purpose into consideration, and weighs their proportion of influence to determine which test has preference in a specific case. This action greatly enhances convenience and operation for the arbitral tribunal to identify indirect expropriation in practice, fully assimilating the advantages from both the standard of Sole Effect Test and the standard of Purpose Test.

\section{The Choice and Application of Standards of Indirect Expropriation}

\subsection{The Choice of the Standard of Effect and Purpose Test}

It is the trend of international community to apply the standard of Effect and Purpose Test to identify the standards of indirect expropriation. The reason is that the standard of Sole Effect Test can help fully protect the interests of foreign investors but add the host country's burden; and the standard of Purpose Test safeguards the public interests of the host country without giving any compensation to foreign investors for their losses; while the standard of Effect and Purpose Test can balance the effect and purpose factors that cause foreign investors' losses by the host country.

Obviously, under the standard of Effect and Purpose Test, the effect may be taken as priority while the purpose is also considered, or the purpose may be taken as priority as well as the effect. Faced with these two situations, the principle of proportionality is introduced. For example, in Tecmed v. Mexico case[4] heard by the arbitration tribunal of International Centre for Settlement of Investment Disputes (ICSID), on the basis of public interests, the Mexican government advocated to refuse Tecmed's claim for continuing the right to use local land, but the tribunal held that identifying the standard of indirect expropriation should take into consideration the proportion between governmental protection for public interests and the adverse influence on foreign investors. In that case, the arbitral tribunal believed that the influence of Mexican governmental action on foreign investors was much serious, so it decided that the Mexican government needed to compensate Tecmed.

\subsection{Exclusions of Indirect Expropriation}

In order to avoid unlimited expansion of the scope of indirect expropriation, some exclusion should be considered such as national security, public health, environmental protection as well as their corresponding influential degree and proportions. For instance, in the issue of environmental protection, the host country's action should not only meet the environmental needs, but also ensure that the environmental benefits achieved far outweigh the losses suffered by foreign investors, and then it will not be identified as indirect expropriation. In practice, however, the proportion of environmental benefits and the losses of foreign investors is difficult to be identified, the decisions to similar cases are different. In Metalclad v. Mexico case [6]heard by ICSID arbitral tribunal, the tribunal held that the Mexican government damaged the company's expected profits based on environmental protection needs by refusing to license Metaldad without pointing out any problems and defects in physical structures. In addition, the damage was only on Metaldad without involving other investors. So the tribunal decided indirect expropriation was identified. However, in Methanex v. United States case, after California enacted a law to protect water resources, Methanex's products were greatly influenced. The arbitral tribunal believed if the action of the host country was consistent with the public interests, non-discriminatory, and followed the provisions of relevant laws, and it not only influenced foreign investors but also domestic investors, it could not be identified indirect expropriation unless the host country committed to compensate when implementing the action. [7] Therefore, the arbitral tribunal decided that the U.S. government's action was general regulatory measure rather than indirect expropriation. As can be seen from the cases above, when the arbitral tribunal identifies public interests, the scale of the influence by the management of the host country is usually considered: when the scale of influence is limited to particular foreign investors, the action is usually identified as indirect expropriation; when the influence expands to all investors at the territory of the host country, the action is often identified as general regulatory measure.

\section{Acknowledgements}

Supported by Beijing Co-construction Project for Central Colleges and Universities.

\section{References}

[1] Id. at 10-11 (quoting Starrett Housing Corp. v. Islamic Republic of Iran, 4 Iran-U.S. C.T.R. 122, 154 (1983)

[2] Tippets, Abbett, McCarthy, Stratton v. Iran, Award of 22 June 1984, 6 Iran-US CTR 219

[3] See Ronald S. Lander v. The Czech Republic. UNCTRAL Award of 10 September 2001. Para 77

[4] See Tecnicas Medioambienales TECMED S.A.v. The United Mexican States. See ICSID Case $\mathrm{ARB}(\mathrm{AF}) / 00 / 2$. Award of May 29. 2003. Para $121: 122$

[5] Stephan W. Schill. The Multilateralization of International Investment Law[M].New York: Cambridge University Press. 2009

[6] See Metalclad Corporation v. the United Mexican States. ICSID Case No.ARB(AF)/97/1.Para 94

[7] See Methanex v. United States. Final Award of the Tribunal on Jurisdiction and Merits .08/03/05. Para 7 